Asian-Australasian Journal of

Food Safety and Security

ISSN 2523-1073 (Print) 2523-2983(Online)

www.ebupress.com/journal/aajfss

\title{
Article \\ Socio-economic status of buffalo farmers and management practices of buffaloes in selected areas of Jamalpur district in Bangladesh
}

\author{
Md. Samiul Haque ${ }^{1}$, Md. Jahangir Alam ${ }^{1 *}$, Lam Yea Asad ${ }^{2}$, Md. Enayet Kabir ${ }^{1}$ and Tahmina Sikder ${ }^{3}$ \\ ${ }^{1}$ Department of Animal Production and Management, Sher-e-Bangla Agricultural University, Dhaka-1207, \\ Bangladesh \\ ${ }^{2}$ Department of Animal Nutrition, Genetic and Breeding, Sher-e-Bangla Agricultural University, Dhaka-1207, \\ Bangladesh \\ ${ }^{3}$ Department of Pathology, Sher-e-Bangla Agricultural University, Dhaka-1207, Bangladesh
}

${ }^{*}$ Corresponding author: Md. Jahangir Alam, Department of Animal Production and Management, Sher-e-Bangla Agricultural University, Sher-e-Bangla Nagar, Dhaka-1207, Bangladesh. Phone: +8801712618555; E-mail: jangalam@yahoo.com, enayet_apma@sau.edu.bd

Received: 14 October 2020/Accepted: 25 November 2020/ Published: 30 November 2020

\begin{abstract}
A field survey was conducted to investigate the farmers' socio-economic status and management practices of buffaloes along with profitability analysis of buffalo rearing at Madargonj upazila of Jamalpur district. The data were collected during October to December 2018 from 60 buffalo keepers randomly selected from four unions of Madargonj upazila through pre-tested and pre-designed interview schedule. Buffalo rearing was practiced by the middle (30-40 years) aged farmers $(51.7 \%)$ and almost three fourth of the farmers were illiterate. Buffalo keepers (40\%) had medium sized family and belonged to small category of farmers (50\%). Farmers usually purchased one pair of buffaloes and reared for 2 years but they (86.7\%) reared buffaloes as their family heritage without any training. Majority of the farmers reared crossbred buffaloes having herd size of 4-10 buffaloes. Buffalo houses were constructed by straw (63.4\%), tin (28.3\%) and only $8.3 \%$ half building. Buffaloes were fed usually with locally available river side grasses and concentrate feeding was not found in majority of cases $(75 \%)$. Natural service was the major practice for breeding of their buffaloes. The most prevalent disease is foot and mouth disease although buffaloes were affected by others. Most of the farmers (66.7\%) performed wallowing of their buffaloes once a day. Yearly expenditure, gross income and net income were Tk. 9570, Tk. 26400 and Tk. 16830; respectively indicating that buffalo rearing is highly profitable in Madargonj. The annual food and cloth purchasing capacity of the buffalo farmers were found to be increased to 65.60 and $57.24 \%$, respectively along with other parameters. The findings of this study clearly indicated that socio-economic profile of buffalo farmers was improved through buffalo rearing although the management practices need to be improved with scientific approaches.
\end{abstract}

Keywords: socio-economic status; livelihood improvement; management practices; buffalo; cost-benefit

\section{Introduction}

Agriculture is the backbone of rural economy in many developing countries of the Asian region including Bangladesh and livestock plays a pivotal role in agriculture. Buffalo (Bubalus bubalis) is one of the important livestock species that holds strategic place next to the cattle in overall livestock economy of Bangladesh and it alone contributes about $2.0 \%$ and $0.94 \%$ to the total milk, and meat production in the country, respectively (DLS, 2015). Buffalo attributes to the farmer's household livelihood generating draft, meat, by-products, milk and milk products, especially as a lucrative income provider (Wanapat and Ampapon, 2017). Buffalo is an important animal to boost up agricultural economy in many tropical and subtropical countries (Suhail et al., 2009). 
There are 1.485 million buffaloes in Bangladesh (BER, 2018) which are found mostly in the BrahmaputraJamuna flood plain of central Bangladesh and Ganges-Meghna flood plain of southern Bangladesh and in institutional herds (Faruque, 2000). Buffalo has seldom been appreciated or recognized and remained neglected species in Bangladesh despite its important role in the national economy. Buffaloes rearing play an important role in improving the livelihood status of the rural farmers especially women and development of this sector could be a potential pathway for rural prosperity (Kalash et al., 2009).

In fact, buffaloes are known for their hardiness, disease resistance, better capacity of converting coarse feed stuffs into quality milk and meat, survival on little inputs, outstanding draught capacity and adaptability to climatic hazard prevalent in Bangladesh. Due to geographical location, favorable weather, abundant natural green grasses in the river basin of old Brahammaputra and Jumuna River, ecology and lack of employment opportunities, people at Madargonj upazila of Jamalpur district in Bangladesh are involved in buffalo rearing extensively. The performance of buffaloes in the region appears to be at low level and the factors responsible need greater attention.

However, performance of buffaloes depend on both the genetic makeup and environment i.e., management practices under which they are reared and these managerial practices exhibits high variation across various agroecological regions. The adoption of management practices by buffalo keepers usually depends on the type of production in which they are involved. Adoption of good management practices ensures better health of buffaloes that promotes their productivity. Exposure and use of appropriate information by buffalo owners will help them to improve knowledge enabling them to obtain more output from their buffaloes, thereby help them to move out from the poverty.

There are several production systems of buffaloes based on management practices and feeding systems in Bangladesh (Saadullah, 2012; Rahman et al., 2018). There are several published reports regarding farmers' socio-economic profile and management practices of buffaloes (Faruque et al., 1995; Sarkar et al., 2013; Amin et al., 2015; Hasan et al., 2016; Uddin et al., 2016; Rahim et al., 2018; Kabir et al., 2020) in various regions of Bangladesh. So far we are aware; a few literatures are available regarding socioeconomic status of the buffalo keepers along with buffalo management practices in the study area. Understanding the husbandry practices prevailed among the buffalo raisers is necessary to find out the strengths and weaknesses of the management systems and also to formulate suitable intervention policies. Therefore, the present investigation was undertaken to obtain first-hand information on the socio-economic characteristics of buffalo keepers and existing buffalo management practices being followed by the buffalo keepers in selected Brahmaputra-Jamuna flood plain river basin area of Jamalpur district along with cost-benefit analysis and livelihood changes of farmers towards buffalo rearing. The information obtained from this study could serve as a basis of exploitation of genetic potentiality of buffaloes, adopting feasible and relevant scientific management practices for buffalo development in the surveyed area.

\section{Materials and Methods}

\subsection{Study site and farmers' selection}

The study was conducted at four unions of Madargonj upazila of Jamalpur district in Bangladesh (Figure 1). A total of 60 farmers from four unions namely Balijuri (25), Char Pakerdha (15), Jorekhali (10), Karaichura (10) were selected adopting PPRS (Proportional Probability Random Sampling) technique of Lahiri (Snedecor and Cochrane, 1989). Farmers who had at least two buffaloes were involved in this study.
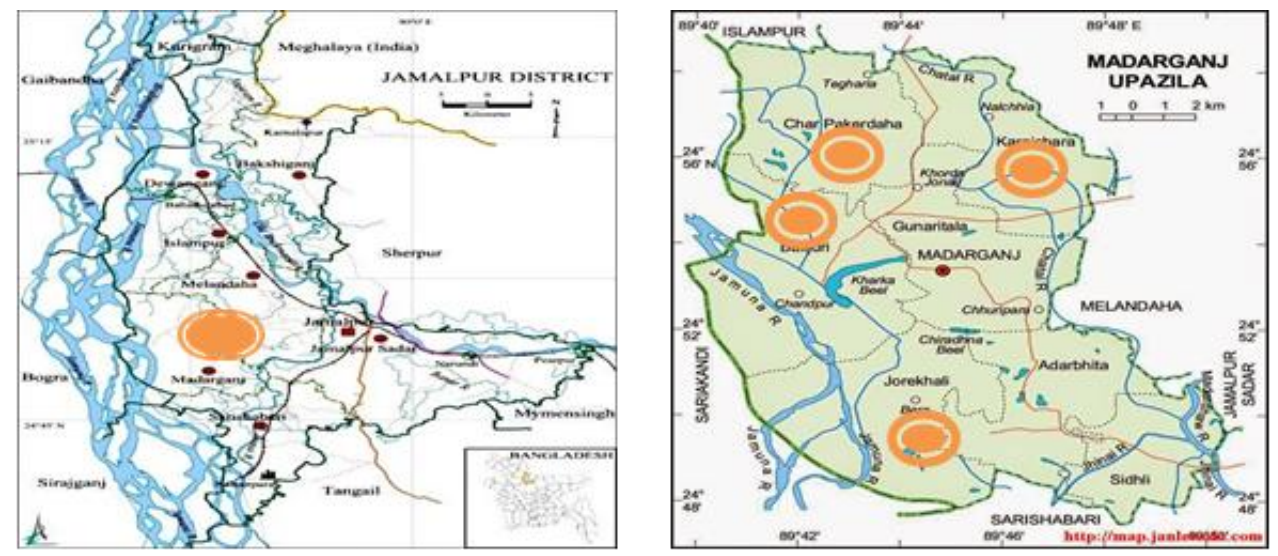

Figure 1. Location map of the study area. 


\subsection{Preparation of interview schedule and data collection}

A structured interview schedule was carefully prepared based on the objectives of the study. The questionnaire contained in the schedule was simple, direct and easily understandable by the respondents. The schedule contained open and closed form of questions. The draft interview schedule was pre-tested in the selected areas and modified accordingly. Data were collected during the period of 5 October to 30 December 2018 through face to face interview from individual buffalo farmers. Before making interview, the objectives of the study were explained clearly to the respondents. Then the questions were asked in a very simple manner with explanation wherever necessary. To collect necessary information from the respondents both interviewing and observation were applied.

\subsection{Proximate analysis of available feedstuffs}

Proximate analysis of some locally available feeds and fodders fed to buffaloes were done in the Animal Nutrition Laboratory of Department of Livestock Services (DLS), Dhaka. Representative samples of feeds and fodder were collected from the selected areas, mixed thoroughly, dried, grinded by grinding machine (CYCLOTEC 1093 Sample mill Tecator, Sweden) at the size of $0.5 \mathrm{~mm}$ for chemical analysis according to the methods of AOAC (2004) and estimated CP (crude protein), CF (crude fiber), EE (ether extract), NFE (nitrogen free extract) and ash of feeds and fodder.

\subsection{Statistical analysis of data}

Collected data from the farmers were checked and cross checked before transferring to the master sheets. The data was analyzed through SPSS-v-16 computer package program.

\section{Results and Discussion}

\subsection{Socio-economic profile of the farmers}

The findings (Table 1) revealed that about half $(51.7 \%)$ of the buffalo farmers were middle aged (30-40 years) since they played a major role in income generation for the family followed by old aged (25\%) and young aged (23.3\%) farmers. Kabir et al. (2020) reported that buffalo rearing was practiced by farmers $(47.5 \%)$ in the age group of 31-45 years in coastal regions of Bangladesh. Three fourth of the farmers can't read and write, and there were no degree passed or Hon's passed farmer in the study area. About $40 \%$ farmers family size was medium (5-7 persons per family). Almost half of the farmers (50\%) belonged to small category (0.20-1.0 acres land) of farmers. The highest percentages of the surveyed farmers $(50 \%)$ were engaged in agriculture including rearing other livestock (Table 1). Most of the farmers $(86.7 \%)$ practiced buffalo rearing without any training as their family profession and/or by the influence of neighboring buffalo farmers but rest of the farmers (13.3\%) took different training on livestock at a short time course by NGO, upazila livestock office etc. on poultry farm management, small scale rural goat farming. The present findings are in accordance with the observation of Siddiki et al. (2015) who reported that more than three fourth of the farmers at Lalpur upazila of Natore district practiced buffalo rearing as their family heritage and rest of them were influenced by the neighboring farmers. There were $41.7 \%$ farmers who used own capital and rest of them managed capital having loan from bank or NGOs like Action for Social Advancement (ASA), Palli Karma-Sahayak Foundation (PKSF) etc. to and other sources for purchasing and/or rearing buffaloes. Majority (65\%) of the farmers took bank loan to purchase their buffaloes and rest of them were used their own capital to rear buffaloes in Bagerhat district (Sarkar et al., 2013). Considering the purchasing ability of farmers, highest percentage (58\%) of the farmers purchased two buffaloes at a time for rearing and draught purpose.

\subsection{Buffalo herd composition and duration of rearing}

The majority (66.7\%) of the herds comprised of $4-10$ buffaloes and about $18.3 \%$ and $15 \%$ farmers had $1-3$ and above 10 herd size, respectively. More than half (56.7\%) of the farmers reared crossbred buffaloes followed by indigenous $(33.3 \%)$ and mixed, indigenous and crossbred type $(10 \%)$ buffaloes. Majority of the surveyed farmers kept buffaloes for 2 years.

\subsection{Housing of buffaloes}

A few number $(8.3 \%)$ of the buffalo keepers provided half building shed where $91.7 \%$ of the farmers used tin shed and straw shed for housing their buffaloes (Table 2). Highest percentage of the farmers (70\%) provided open house followed by closed house (30\%). In another region of the country, Uddin et al. (2012), observed that highest percentage of the dairy cattle farmers $(77.5 \%)$ provided open house, $22.5 \%$ provided closed and semiclosed house. Significantly higher $(86.7 \%)$ percentage of the respondents had kutcha floor in their buffaloes 
shed and about $83.3 \%$ had drainage channel. These findings are in line with the observations of Rahman et al. (2018) who reported that some farmers constructed floor by brick, some sheds have roofs using tin of Subornachar upazila in Bangladesh. Maximum farmers (86.7\%) provided adequate ventilation in buffalo houses/shed. Regarding the summer and winter management in buffaloes, majority of the farmers $(66.7 \%)$ practiced summer management practices to protect buffaloes from extreme heat and took management care to protect buffaloes from extreme cold.

\subsection{Feeds and feeding management}

\subsubsection{Feed management}

The majority $(63.3 \%)$ of buffalo owners practiced semi-intensive system followed by extensive (36.7\%) feeding methods (Table 2). The similar findings were also noticed by Sarkar et al. (2013) who reported that semiintensive feeding system was practiced in the Bagerhat district followed by extensive system but no one practiced intensive feeding system. The highest percentage (58.3\%) of the farmers used river side area (char) grass where there was no farmers' who depends on others people land as source of buffalo feed. About $70 \%$ of the respondents seemed that feeds and fodder were available in the study area but three fourth of the respondents did not practice concentrate feeding to their buffaloes. Almost three fourth $(70 \%)$ of the surveyed farmers were habituated in once feeding a day followed by twice feeing a day (30\%) to their buffaloes (Table 2). All of the surveyed farmers practiced giving water to their buffaloes ad libitum in quantity but restricted in frequencies in which 2 times a day was followed by most of the farmers (80\%) while only $20 \%$ of the farmers practiced free access of water to their buffaloes. Tanmay et al. (2002) reported that water is provided twice a day in summer and once a day in winter to their buffaloes and is a common practice followed by most of the buffalo keepers. Regular practice regarding adding salt or mineral mixture in water for feeding of buffaloes was done by $53.3 \%$ (highest) respondents where irregular was done by only $16.7 \%$ respondents but $30 \%$ respondents did not practice at all (Table 2).

\subsubsection{Chemical composition of feedstuffs fed to buffaloes}

The local grass in study areas like dhubla/dubra, dhal, helencha contains $16.5 \%, 8.1 \%, 20.2 \%$ of crude protein respectively. It was observed (Table 3 ) that helencha contain more crude protein than others and low amount of crude fiber. So, helencha grass is suitable to growth muscle and reproduction of buffalo in this area. Straw contains high crude fiber (CF) which could not easily be digested by buffalo but other grasses in the selected areas easily utilized by buffaloes due to low amount of crude fiber. Lower CF content in the feedstuffs indicated a good quality feeds for buffaloes. Dhal grass contains more a $\mathrm{h}$ which supply mineral and dubra contain more dry matter which help to supply better nutrient in buffalo. Among the feeds (rice polish, broken rice, straw), the rice polish comparatively contain more nutrient than others. Reports on similar studies were also available from different authors (Sarker et al., 2013; Amin et al., 2015; Siddiki et al., 2015).

\subsection{Breeding practices}

The results of the present study revealed (Table 4) that the highest percentage (58.3\%) of buffalo keepers practiced only natural mating. Higher proportion of use of natural service may be due to the non-availability of good infrastructure facilities for artificial insemination (AI), preservation and timely AI services in the study area. Sawarkar et al. (2001) reported that, most of the farmers preferred natural service only due to various reasons. Hasan et al. (2016) observed that only $25.71 \%$ farmers practiced artificial insemination for oestrous synchronization in Bhola district. Most of the farmers reported that they cannot detect heat properly but no one used teaser bull to detect heat. These findings have similarities with the observations of Hole (2016) who found that $100 \%$ of the respondents detect their buffaloes in heat by using symptoms. Among the various behavioral signs of estrus, majority (41.7\%) of farmers believed on mounting and urination as the symptoms of heat, whereas $25 \%$ of the farmers trusted on bellowing and discharge, followed by mucus discharge (23.3\%) and frequent urination $(10 \%)$.

\subsection{Wallowing of buffaloes}

Wallowing is an important way for buffaloes to maintain its physiothermic regulation. In the studied areas, most of the farmers (66.7\%) performed wallowing of their buffaloes once a day (Table 4). The buffaloes are interested to wallow but farmers didn't allow too much time to wallow. Maximum farmers maintained wallowing of their buffaloes in beel and river water as there are many rivers (Jhinai, Jamuna, Chatal river) and beels (Chiradhuna Beel, Kharka Beel etc.) in the study area. 
3.7. Health care practices

About 66.7 and $60 \%$ farmers performed vaccination and deworming in their buffaloes, respectively (Table 4). The incidence of foot and mouth disease (FMD) (56.7\%) was higher than other diseases like black quarter (BQ) (20\%), anthrax (13.3\%) and mastitis (10\%). Siddiki et al. (2015) found that the incidence of foot and mouth disease, black quarter, anthrax and hemorrhagic septicemia were 53, 25, 15 and $7 \%$ respectively at Lalpur upazila of Natore district. Source of vaccines, anthelmentics and medicine is also an important factor to control diseases of buffaloes. Majority of the respondents (65\%) depended on local market as source of vaccines, anthelmentics and medicine. Almost three fourth $(73.3 \%)$ of the respondents were dependent on quacks for the treatment of their sick buffaloes due to ignorance and lack of veterinary facilities in their locality. It was observed that most (78.3\%) of the respondents belong to good to satisfactory sanitary system (Table 4).

\subsection{Marketing system of buffaloes}

Maximum farmers (73.3\%) purchased their buffaloes from local market followed by another buffalo farmer (26.7\%) (Table 4). Buffaloes were taken to local market for selling, on market days (Hut). Highest percentage of the respondents (43.3\%) sold their buffaloes to whole seller where lowest percentage (15\%) of the respondents sold their buffaloes to consumers. In the process of buffaloes marketing middlemen and butchers are also involved. Buying and selling are completed through bargaining practice.

\subsection{Economics of buffalo rearing}

\subsubsection{Cost of buffaloes}

The price of buffaloes varies according to the size, body condition, health status, milk production and utility. The price of a pair of buffaloes for dual purpose ranged from Tk. 90,000 to Tk. 200000 in this study area. But the highest percentage of the farmers noticed that the average cost of one pair of buffalo purchasing was Tk. 90000 to Tk. 100000. Amin et al. (2015) found the price of a pair of buffaloes for dual purpose ranged from Tk. 80000 to Tk. 180000 at Subornochar upazila of Noakhali district, which is almost similar with the present study.

\subsubsection{Rearing cost of buffaloes}

The cost of feeding, breeding, housing, equipment and treatment is presented in Table 5. The average cost of labor (per year) was higher than the average cost of feed, housing and equipment, breeding, veterinary doctor and medicine and vaccine (per year). Farmers generally bred their buffalo from the neighbor's buffalo bull and they sometimes artificially inseminate their buffaloes. For this reason, the breeding cost was low. On the other hand, they usually did not purchase feed for their buffaloes but during scarcity they purchase feed i.e., straw only. The average rearing cost of one buffalo per year was Tk. 9570. Amin et al. (2015) reported that the rearing cost of one buffalo was Tk. 6850 in Subornochar upazila of Bangladesh. The rearing cost was found higher in Madargonj than that from Subornochar.

\subsubsection{Income from buffalo rearing}

The average income per year per buffalo through draught was Tk. 15000 followed by milk (Tk. 10000) and dung (Tk. 1400) (Table 5). The net income from one buffalo per year was Tk. 16830. It indicates that rearing of buffaloes in the selected areas was profitable. The findings of the present study coincide with the findings of Sarkar et al. (2013) who also reported that the annual net income from rearing one buffalo was Tk. 15630.

\subsection{Livelihood improvement of buffalo farmers}

The buffalo farmers spent $65.60,57.24,40.00,28.00,43.61$ and $18.18 \%$ higher money for purchasing food, cloth, maintaining social status, education, health care and housing respectively (Table 6) after they started rearing buffaloes which indicated that livelihood status of buffalo keeping families was improved in the studied areas. The similar findings were also noticed by Sarkar et al. (2013) who reported that livelihood increased dramatically through buffalo rearing in Bagerhat. Hasan et al. (2016) stated that buffalo rearing in the coastal areas of Bangladesh was highly profitable. Rahman et al. (2008) reported that the benefit cost ratio was 1.31, indicating that buffalo rearing was profitable in Bangladesh which is agreed with the findings of Islam et al. (2017) and Siddiki et al. (2017) and also support to the findings of present study. 
Table 1. Socioeconomic profile of the farmers, $(n=60)$.

\begin{tabular}{|c|c|c|c|}
\hline Variables & Categories & Frequency & Percentage \\
\hline \multirow{3}{*}{ Age (Years) } & Young aged (25-30) & 14 & 23.3 \\
\hline & Middle aged (30-40) & 31 & 51.7 \\
\hline & Old aged (Above 40) & 15 & 25 \\
\hline \multirow{5}{*}{ Level of education } & Cannot read and write & 45 & 75 \\
\hline & Can sign only & 8 & 13.3 \\
\hline & Primary (1-5) & 5 & 8.3 \\
\hline & Below SSC (6-10) & 2 & 3.4 \\
\hline & Higher level (above 10) & 0 & 0 \\
\hline \multirow{3}{*}{ Family size (number) } & Small family (up to 4) & 17 & 28.3 \\
\hline & Medium family ( 5-7) & 24 & 40 \\
\hline & Large family (above 7) & 19 & 31.7 \\
\hline \multirow{5}{*}{ *Farmers' type } & Landless farmer (below $0.02 \mathrm{ha}$ ) & 0 & 0 \\
\hline & Marginal farmer $(0.02-0.2 \mathrm{ha})$ & 9 & 15 \\
\hline & Small farmer $(0.2-1 \mathrm{ha})$ & 30 & 50 \\
\hline & Medium farmer(1- 3 ha) & 20 & 33.3 \\
\hline & Large farmer( above $3 \mathrm{ha}$ ) & 1 & 1.7 \\
\hline \multirow{4}{*}{ Occupation } & Only buffalo rearing & 22 & 36.7 \\
\hline & Crop farming & 5 & 8.3 \\
\hline & Agriculture plus livestock rearing & 30 & 50 \\
\hline & Chicken and duck rearing & 3 & 5 \\
\hline \multirow{2}{*}{ Training received } & Yes & 8 & 13.3 \\
\hline & No & 52 & 86.7 \\
\hline \multirow{3}{*}{$\begin{array}{l}\text { Source of capital/ } \\
\text { Financial support }\end{array}$} & Own capital & 25 & 41.7 \\
\hline & Loan from bank & 27 & 45 \\
\hline & NGOs & 8 & 13.3 \\
\hline \multirow{3}{*}{ Purchase at a time } & One & 10 & 16.7 \\
\hline & Two & 35 & 58.3 \\
\hline & More than two & 15 & 25 \\
\hline
\end{tabular}

*FAO (2008)

Table 2. Housing and feeding management practices, $(n=60)$.

\begin{tabular}{|c|c|c|c|c|}
\hline Practices & Parameters & Categories & Frequency & Percentage \\
\hline \multirow{4}{*}{ 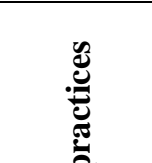 } & \multirow{3}{*}{ Nature of house } & Tin shed & 17 & 28.3 \\
\hline & & Straw shed & 38 & 63.4 \\
\hline & & Half building & 5 & 8.3 \\
\hline & \multirow{2}{*}{ Housing system } & Open & 42 & 70 \\
\hline \multirow{9}{*}{ 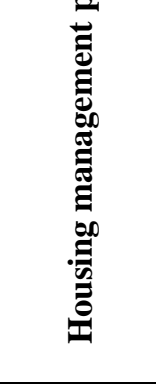 } & & Closed \& semi-closed & 18 & 30 \\
\hline & \multirow{2}{*}{ Floor type } & Pucca & 8 & 13.3 \\
\hline & & Kutcha & 52 & 86.7 \\
\hline & \multirow{2}{*}{$\begin{array}{l}\text { Ventilation } \\
\text { facilities }\end{array}$} & Adequate & 52 & 86.7 \\
\hline & & Not adequate & 8 & 13.3 \\
\hline & \multirow{2}{*}{ Drainage channel } & Yes & 50 & 83.3 \\
\hline & & No & 10 & 16.7 \\
\hline & \multirow{2}{*}{$\begin{array}{l}\text { Summer and winter } \\
\text { management }\end{array}$} & Practiced & 40 & 66.7 \\
\hline & & Not practiced & 20 & 33.3 \\
\hline \multirow{10}{*}{ 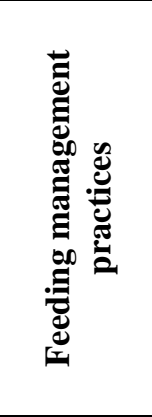 } & \multirow{3}{*}{$\begin{array}{l}\text { Type of feeding } \\
\text { methods }\end{array}$} & Extensive & 22 & 36.7 \\
\hline & & Semi-intensive & 38 & 63.3 \\
\hline & & Intensive & 0 & 0 \\
\hline & \multirow{4}{*}{ Sources of feed } & River side area (char) grass & 35 & 58.3 \\
\hline & & Own land cultivated grass & 7 & 11.7 \\
\hline & & Others people land & 0 & 0 \\
\hline & & Roadside green grass and unconventional feed & 18 & 30 \\
\hline & \multirow{2}{*}{$\begin{array}{l}\text { Feeds and fodder } \\
\text { availability }\end{array}$} & Available & 42 & 70 \\
\hline & & Not available & 18 & 30 \\
\hline & Feeding & Homemade concentrate (Rice broken, Rice polish, etc.) & 10 & 16.7 \\
\hline
\end{tabular}


Asian Australas. J. Food Saf. Secur. 2020, 4 (2)

\begin{tabular}{|l|l|l|l|}
\hline \multirow{2}{*}{ concentrate } & Purchased (Wheat bran, Mustard oil cake) & 5 & 8.3 \\
\cline { 2 - 4 } & Not feeding & 45 & 75 \\
\hline \multirow{3}{*}{$\begin{array}{l}\text { Frequency of } \\
\text { feeding }\end{array}$} & Once & 42 & 70 \\
\cline { 2 - 4 } & Twice & 18 & 30 \\
\cline { 2 - 4 } & Three times & 0 & 0 \\
\hline \multirow{2}{*}{$\begin{array}{l}\text { Frequency of } \\
\text { watering }\end{array}$} & 2 times & 48 & 80 \\
\hline \multirow{2}{*}{$\begin{array}{l}\text { Add salt or mineral } \\
\text { mixture in water }\end{array}$} & Free access of water & 12 & 20 \\
\cline { 2 - 4 } & Regular & 32 & 53.3 \\
\cline { 2 - 4 } & Irregular & 10 & 16.7 \\
\hline
\end{tabular}

Table 3. Chemical composition of feedstuffs fed to buffaloes in the study areas.

\begin{tabular}{|l|l|l|l|l|l|l|}
\hline \multirow{2}{*}{ Feedstuffs } & \multicolumn{5}{|c|}{ Chemical composition (\% DM basis) } \\
\cline { 2 - 8 } & DM & CP & CF & EE & NFE & Ash \\
\hline Broken rice & 88.5 & 9.2 & 23.5 & 2.3 & 62.7 & 2.3 \\
\hline Rice polish & 92.3 & 10.7 & 11.7 & 10.6 & 51.2 & 15.8 \\
\hline Straw & 86.8 & 3.6 & 35.8 & 1.5 & 44.9 & 14.2 \\
\hline Dhubla/durba grass (Cynodon dactylon) & 90.2 & 16.5 & 32.6 & 1.9 & 36.4 & 12.6 \\
\hline Dhal grass (Hymenachne amplexicaulis) & 89.6 & 8.1 & 29.5 & 1.4 & 40.9 & 20.1 \\
\hline Helencha (Enhydra fluctuans) & 86.4 & 20.2 & 16.8 & 13.4 & 43.2 & 6.4 \\
\hline
\end{tabular}

Table 4. Breeding, wallowing, health care and marketing management practices, $(n=60)$.

\begin{tabular}{|c|c|c|c|c|}
\hline Practices & Parameters & Categories & Frequency & Percentage \\
\hline \multirow{11}{*}{ 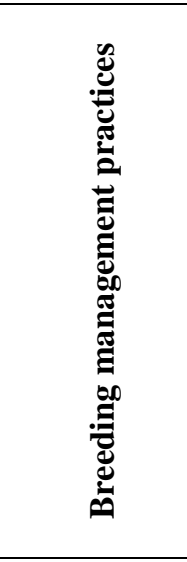 } & \multirow{3}{*}{ Breeding method } & Artificial insemination (AI) & 10 & 16.7 \\
\hline & & Both AI and Natural & 15 & 25 \\
\hline & & Only natural & 35 & 58.3 \\
\hline & \multirow{2}{*}{ Heat detection } & Yes & 25 & 41.7 \\
\hline & & No & 35 & 58.3 \\
\hline & \multirow{2}{*}{ Methods of heat detection } & Symptoms & 60 & 100 \\
\hline & & Teaser & 00 & 00 \\
\hline & \multirow{4}{*}{ Symptoms of heat detection } & Mucus discharge & 14 & 23.3 \\
\hline & & Mounting and urination & 25 & 41.7 \\
\hline & & Bellowing and discharge & 15 & 25 \\
\hline & & Frequent urination & 6 & 10 \\
\hline \multirow{2}{*}{$\begin{array}{l}\text { Wallowing } \\
\text { of buffaloes }\end{array}$} & \multirow{2}{*}{ Wallowing frequency } & Once a day & 40 & 66.7 \\
\hline & & Twice a day & 20 & 33.3 \\
\hline \multirow{14}{*}{ 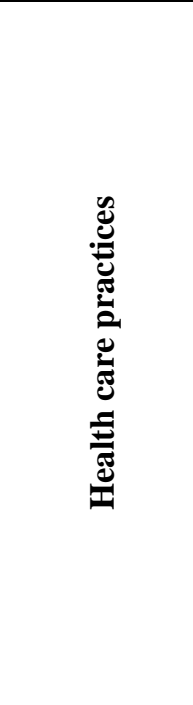 } & \multirow{2}{*}{ Practice of vaccination } & Yes & 40 & 66.7 \\
\hline & & No & 20 & 33.3 \\
\hline & \multirow{2}{*}{ Practice of deworming } & Yes & 36 & 60 \\
\hline & & No & 24 & 40 \\
\hline & \multirow{2}{*}{ Practice to control ecto-parasites } & Followed & 31 & 51.7 \\
\hline & & Not followed & 29 & 48.3 \\
\hline & \multirow{4}{*}{ Incidence of diseases } & Anthrax & 8 & 13.3 \\
\hline & & FMD & 34 & 56.7 \\
\hline & & $\mathrm{BQ}$ & 12 & 20 \\
\hline & & Mastitis & 6 & 10 \\
\hline & \multirow{3}{*}{$\begin{array}{l}\text { Source of vaccines, anthelmentics, } \\
\text { medicine }\end{array}$} & Local market & 39 & 65 \\
\hline & & Livestock office & 16 & 26.7 \\
\hline & & Calling quack & 5 & 8.3 \\
\hline & Treatment of sick buffaloes & Veterinary doctor & 16 & 26.7 \\
\hline
\end{tabular}




\begin{tabular}{|c|c|c|c|c|}
\hline & & Quacks & 44 & 73.3 \\
\hline & \multirow{3}{*}{ Sanitary condition of shed } & Good & 21 & 35 \\
\hline & & Satisfactory & 26 & 43.3 \\
\hline & & Poor & 13 & 21.7 \\
\hline \multirow{6}{*}{ 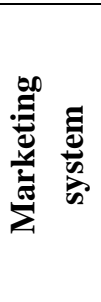 } & \multirow{2}{*}{ Purchased from } & Local market & 44 & 73.3 \\
\hline & & Another farmer & 16 & 26.7 \\
\hline & \multirow{4}{*}{ Sold to } & Whole seller & 26 & 43.3 \\
\hline & & Middleman & 10 & 16.7 \\
\hline & & Butcher & 15 & 25 \\
\hline & & Consumer & 9 & 15 \\
\hline
\end{tabular}

Table 5. Cost and returns from buffalo rearing (yearly per buffalo), $(n=60)$.

\begin{tabular}{|l|l|l|l|}
\hline \multicolumn{2}{|c|}{ Cost } & \multicolumn{2}{c|}{ Return } \\
\hline Items & Amount (Tk.) & Items & Amount (Tk.) \\
\hline Feed & 2360 & Draught & 15000 \\
\hline Housing and equipment & 2240 & Milk sale & 10000 \\
\hline Breeding cost & 520 & Value of dung & 1400 \\
\hline Labor charges & 3150 & & \\
\hline Veterinary doctor and medicine cost & 1000 & & \\
\hline Vaccine & 300 & & \\
\hline Total Cost & $\mathbf{9 5 7 0}$ & Total Return & $\mathbf{2 6 4 0 0}$ \\
\hline \multicolumn{2}{|l}{} \\
\hline
\end{tabular}

Table 6. Impact of buffalo rearing on livelihood activities.

\begin{tabular}{|l|l|l|l|l|}
\hline Category & Initial value (Tk.) & Final value (Tk.) & Difference (\%) & Rank of order \\
\hline Food Purchasing & 860 & 2500 & 65.60 & 1 \\
\hline Cloth Purchasing & 620 & 1450 & 57.24 & 2 \\
\hline Health care & 750 & 1430 & 43.61 & 3 \\
\hline Social status & 1200 & 2000 & 40.00 & 4 \\
\hline Education & 540 & 750 & 28.00 & 5 \\
\hline Housing & 440 & 18.18 & 6 \\
\hline
\end{tabular}

\section{Conclusions}

The results showed that management practices prevailed among the buffalo keepers were not in tune of standard recommendations rather buffaloes were raised depending upon the knowledge from their ancestors from long age practiced. No attempts were made to improve the buffalo management and production techniques. The result clearly indicated that livelihood increases dramatically through buffalo rearing in the study area although the buffalo farmers need to be provided knowledge and skill through training in scientific management practices.

\section{Acknowledgements}

We are grateful to the farmers who helped us to complete the research work successfully.

\section{Conflict of interest}

None to declare.

\section{References}

Amin MR, MA Siddiki, AKMA Kabir, MO Faruque and ZH Khandaker, 2015. Status of buffalo farmers and buffaloes at Subornochar upazila of Noakhali district in Bangladesh. Prog. Agri., 26: 71-78.

AOAC, 2004. Official Methods of Analysis ( $17^{\text {th }}$ Edn.), Association of Official Analytical Chemists, Arlington, VA, USA.

BER (Bangladesh Economic Review), 2018. Finance Division, Ministry of Finance, Government of the People's Republic of Bangladesh, Dhaka, Bangladesh. 
DLS, 2015. Annual Report on Livestock, Division of Livestock Statistics, Ministry of Fisheries and Livestock, Farmgate, Dhaka, Bangladesh.

FAO (Food and Agriculture Organization of the United Nations), 2008. Production Year Book, Vol. 41.pp-89.

Faruque MO, 2000. Final report of the project-Identification of best genotype of buffalo for dairy purpose in Bangladesh and to improve their productivity. Paper presented at a seminar in Bangladesh Agricultural Research Council, Dhaka, Bangladesh.

Faruque MO and MR Amin, 1995. Indigenous buffaloes in the coastal area of Bangladesh: part-II. Productivity of indigenous buffaloes in the south western coastal area. Bang. J. Train. Develop., 4: 138-140.

Hasan T, S Akter, H Biswas, MA Halim, A Alam and K Rafiq, 2016. Economic analysis of small scale dairy buffalo enterprises in Bhola district of Bangladesh. Prog. Agri., 27: 502-510.

Hole MR, 2016. Studies on management practices followed by cattle and buffalo owners in Latur Tahshil. MSc (Agri) Thesis, Vasantrao Naik Marathwada Agricultural University, Parbhani.

Islam MN, 2017. Challenge of animal protein for national health security: Keynote paper presented at $4^{\text {th }}$ (BSAPER) International Conference, 6 May, 2017. Bangladesh Agricultural University, Mymensingh.

Kabir ME, MM Monir, MS Islam, MJ Alam and F Dadok, 2020. Existing buffalo husbandry practices at household farming level in selected coastal regions of Bangladesh. Asian J. Med. Biol. Res., 6: 255-264.

Kalash P, R Rathore and M Kumar, 2009. Livelihood improvement of farm women through cattle and buffalo rearing in Jhunjhunu district of Rajasthan. Int. J. Rural Stud., 16: 1-3.

Rahim MA, MA Hossain, MA Rahman, MR Amin, MM Hossain and M Hashem, 2018. Socio-economic status of buffalo farmers and the management practices of buffaloes in plain land of Subornachar upazila in Bangladesh. Prog. Agri., 29: 158-167.

Rahman SMA, JB Begum, MA Sayeed, M Hossain and J Alam, 2008: Economics of buffalo production in some selected areas of Bangladesh. Bang. J. Liv. Res., 15: 39-46.

Rahman SM, MN Islam, MH Rashid, MS Siddiki and MA Islam, 2018. Dairy buffalo production system under semi-intensive management in the coastal area of Bangladesh. SAARC J. Agri., 16: 43-59.

Saadullah M, 2012. Buffalo production and constants in Bangladesh. J. Anim. Plant Sci., 22: 221-224.

Sarkar S, MM Hossain and MR Amin, 2013. Socio-economic status of buffalo farmers and the management practices of buffaloes in selected areas of Bagerhat district of Bangladesh. Bang. J. Anim. Sci., 42: 158-164.

Sawarkar SW, MM Borkar, SV Upadhye and SB Jadhao, 2001. Characteristics of dairy owners, their awareness, adoption and constraints in adoption of artificial insemination practices in Vidarbha region. Indian J. Dairy Sci., 54: 194-202.

Siddiki MA, 2017. Improvement of production potential of buffaloes supplemented with protein and energy based diets. PhD thesis, Department of Animal Science, Bangladesh Agricultural University, Mymensingh.

Siddiki MA, MR Amin, AKMA Kabir, MO Faruque and ZH Khandaker, 2015. Socio-economic status of buffalo farmers and the performances of buffaloes at Lalpur upozila of Natore district in Bangladesh. Bang. J. Anim. Sci., 44:157-165.

Snedecor GW and GW Cochrane, 1989. Statistical Methods. $8^{\text {th }}$ Edn. East-west Press, New Delhi, India.

Suhail SM, MS Qureshi, S Khan, Ihsanullah and FR Durrani, 2009. Inheritance of economic traits of dairy buffaloes in Pakistan. Sarhad J. Agric., 25: 87-93.

Tanmay S, M Chander and GP Mondal, 2002. Buffalo feeding practices of Vangujjars- A study in Tanda forest range of Uttranchal state. Indian J. Dairy Sci., 55: 121-123.

Uddin MK, AA Mintoo, TM Awal, M Kondo and AKMA Kabir, 2016. Characterization of buffalo milk production system in Bangladesh. Bang. J. Anim. Sci., 45: 69-77.

Uddin MN, MB Uddin, M Al Mamun, MM Hassan and MMH Khan, 2012. Small scale dairy farming for livelihoods of rural farmers: Constraint and Prospect in Bangladesh. J. Anim. Sci. Adv., 2: 543-550.

Wanapat $\mathrm{M}$ and T Ampapon, 2017. Enhancing buffalo production based on feed resources development and innovations. Proceedings of International Buffalo Symposium, 15-18 November 2017, Chitwan, Nepal. Edited by: Faculty of Animal Science, Veterinary Science and FisheriesAgriculture and Forestry University, p. 63. 